\title{
Tumstatin induces apoptosis and stimulates phosphorylation of p65NF- $\kappa B$ in human osteoblastic osteosarcoma Saos-2 cells
}

\author{
YANG WANG $^{1}$, RUO-FENG YIN ${ }^{1}$ and JIA-SONG TENG ${ }^{2}$ \\ ${ }^{1}$ Department of Orthopaedics, China-Japan Union Hospital of Jilin University, Changchun, Jilin 130033; \\ ${ }^{2}$ Department of Orthopaedics, Daqing Oilfields General Hospital, Daqing, Heilongjiang 163000, P.R. China
}

Received December 30, 2015; Accepted February 11, 2016

DOI: $10.3892 /$ or.2016.4762

\begin{abstract}
The present study was aimed to investigate the effect of tumstatin on inhibition of proliferation and induction of apoptosis in Saos-2 human osteosarcoma cells and to understand the mechanism involved. Inhibition of cell proliferation was analyzed by MTT assay and induction of apoptosis through nuclear fragmentation assay. Viability of Saos-2 cells was reduced to $19 \%$ on treatment with $25 \mu \mathrm{M}$ concentration of tumstatin after $48 \mathrm{~h}$. Presence of characteristic apoptotic nuclei, rounded cell shape and shrunken size were caused by tumstatin treatment at $25 \mu \mathrm{M}$ concentration. The level of mRNA corresponding to PTEN, FasR and FasL was increased significantly in tumstatin treated Saos-2 cells compared to untreated control. Investigation of the mechanism revealed NF- $\kappa$ B activation by phosphorylation on serine 536 . The activated NF- $\kappa \mathrm{B}$ was translocated into the nucleus from the cytoplasm on treatment with tumstatin. Degradation of the I $\kappa \mathrm{B} \alpha$ by tumstatin was found to be much slower compared to that induced by treatment with TNF- $\alpha$. Thus, tumstatin inhibits proliferation and induces apoptosis in Saos- 2 cells through activation of $N F-\kappa B$ and its translocation to the nucleus. Therefore, tumstatin can play an important role in the treatment of osteosarcoma.
\end{abstract}

\section{Introduction}

Osteosarcoma alone comprises more than $50 \%$ of the primary bone tumors and is detected mostly in children. In Japan every year more than 100 cases of osteosarcoma are detected. In osteosarcoma various changes are observed in the chromosomes and the gene mutations are also extensive resulting in the development of complex tumors $(1,2)$. Numerous studies have been performed to understand the mechanism underlying the development of osteosarcoma (1-6). Despite advancement

Correspondence to: Professor Yang Wang, Department of Orthopaedics, China-Japan Union Hospital of Jilin University, No. 126 Xiantai Street, Changchun, Jilin 130033, P.R. China E-mail: wangyangwy@hotmail.com

Key words: apoptosis, inhibition, viability, translocation, tumstatin in the techniques including, wide tumor excision and aggressive chemotherapy the prognosis in osteosarcoma patients is very poor $(7,8)$. Thus, the screening of molecules for effective treatment of osteosarcoma is desired (9).

Apoptosis is the controlled and programmed death of cells and is vital for the treatment of carcinoma and removal of unwanted cells from the body $(10,11)$. Regulation of various factors involved in the process of apoptosis is mediated through phosphorylation (12). One more factor involved in the regulation of apoptosis in various types of carcinoma cells is the nuclear factor-kappa $\mathrm{B}(\mathrm{NF}-\kappa \mathrm{B})(13-17)$. Activation of $\mathrm{I} \kappa \mathrm{B} \alpha$ followed by its degradation induces translocation of $\mathrm{NF}-\kappa \mathrm{B}$ into the cell nucleus from cytoplasm where it influences several genes.

Tumstatin, is a well-known anti-angiogenic agent possessing promising antitumor potential $(18,19)$. Various reports have demonstrated that tumstatin treatment prevents tumor proliferation in glioma and melanoma tumor models (20-22). In addition, tumstatin exhibits a strong tendency to suppress proliferation and angiogenesis of tumor in the head and neck carcinoma models. Furthermore, in oral squamous cancer model treatment with tumstatin inhibited metastasis of carcinoma cells to the lymph nodes (23). The present study was aimed to investigate the effect of tumstatin on tendency of proliferation and apoptosis in Saos-2 osteosarcoma cells. The results demonstrated that tumstatin treatment in Saos-2 cells inhibited cell proliferation and induced apoptosis through activation of $\mathrm{p} 65 \mathrm{NF}-\kappa \mathrm{B}$.

\section{Materials and methods}

Chemicals and reagents. Tumstatin and TNF- $\alpha$ were purchased from Sigma-Aldrich (St. Louis, MO, USA). The stock solution of tumstatin was prepared in dimethyl sulfoxide and stores at $-15^{\circ} \mathrm{C}$ before use in the experiment. Fetal bovine serum (FBS) and Dulbecco's modified Eagle's minimum essential medium (D-MEM) were obtained from Gibco-BRL (Gaithersburg, MD, USA).

Cell culture. Saos-2 osteosarcoma cell line and human embryonic kidney HEK293 cells were obtained from the American Type Culture Collection (ATCC; Rockville, MD, USA). The cells were cultured in D-MEM containing 10\% FBS, 2 mM glutamine, $100 \mathrm{U} / \mathrm{ml}$ penicillin and $100 \mu \mathrm{g} / \mathrm{ml}$ streptomycin. 
Table I. The primers used in RT-PCR.

\begin{tabular}{lll}
\hline Primer & \multicolumn{1}{c}{ Forward } & \multicolumn{1}{c}{ Reverse } \\
\hline PTEN & 5'-ACCGCCAAATTTAATTGCAG-3' & 5'-GGGTCCTGAATTGGAFFAAT-3' \\
FasL & 5'-TCTCAGACGTTTTTCGGCTT-3' & 5'-AAGACAGTCCCCCTTGAGGT-3' \\
FasR & 5'-CAAGGGATTGGAATTGAGGA-3' & 5'-GACAAAGCCACCCCAAGTTA-3' \\
GAPDH & 5'-ACCACAGTCCATGCCATCAC-3' & 5'-TCCACCACCCTGTTGCTGTA-3' \\
\hline
\end{tabular}

Both cell lines were cultured in an incubator of humidified atmosphere with $5 \% \mathrm{CO}_{2}$ at $37^{\circ} \mathrm{C}$.

Analysis of cell proliferation. The effect of tumstatin on proliferation of Saos-2 cells was analyzed by 3-(4,5-dimethylthiazol-2-yl)-2,5-diphenyltetrazolium bromide (MTT; Sigma-Aldrich) assay. The cells were distributed at density of $2 \times 10^{6}$ cells/well in $2 \mathrm{ml}$ DMEM medium supplemented with 10\% FBS in 6-well plates (Nunc A/S Plastfabrikation, Roskilde, Denmark). Following 12-h incubation, the medium was replaced with new medium containing $5,10,15,20,25$ or $30 \mu \mathrm{M}$ concentrations of tumstatin and incubated for $48 \mathrm{~h}$. Then, $50 \mu \mathrm{l}$ of MTT $(5 \mu \mathrm{g} / \mathrm{ml})$ solution was added to each well and incubation was continued for $2 \mathrm{~h}$. To each well of the plate, $150 \mu \mathrm{l}$ of DMSO was added and incubated for $5 \mathrm{~min}$. The well optical density (OD) was recorded at $570 \mathrm{~nm}$ using an EL800 Universal Microplate Reader (BioTek Instruments, Inc., Winooski, VT, USA).

DNA fragmentation assay. Saos- 2 cells were seeded in T-75 flasks at a density of $2 \times 10^{5}$ cells/flask and cultured for $12 \mathrm{~h}$. Then, medium was replaced with new medium containing $25 \mu \mathrm{M}$ concentration of tumstatin for $48 \mathrm{~h}$. QIAamp DNA Mini kit (Qiagen) was used for the preparation of genomic DNA in accordance with the guidelines on the user manual. Electrophoresis of the DNA samples was performed on $1.8 \%$ agarose gel at $50 \mathrm{~V}$ for $2 \mathrm{~h}$. For gel staining ethidium bromide (Sigma-Aldrich) was used, whereas visualization was achieved by ultraviolet (UV) transilluminator (Wealtech Corp., Reno, NV, USA).

DNA isolation and agarose gel electrophoresis. Saos-2 cells after incubation with tumstatin for $48 \mathrm{~h}$ were rinsed three times in PBS and lysed in lysis buffer [ $10 \mathrm{mM}$ Tris- $\mathrm{HCl}$ buffer (pH 7.5), $10 \mathrm{mM}$ EDTA and $0.5 \%$ Triton X-100). The cell lysates were centrifuges at $12,000 \mathrm{x}$ g for $45 \mathrm{~min}$ to remove the insoluble material. The lysate was then treated with DNase and subjected to incubation at $37^{\circ} \mathrm{C}$ for $45 \mathrm{~min}$. The lysates were treated with proteinase $\mathrm{K}$ for $50 \mathrm{~min}$ followed by addition of 2-propanol and $\mathrm{NaCl}$ to precipitate the DNA. DNA was suspended in TE-buffer and then electrophoresed using agarose gel. The UV transilluminator (Vilber Lourmat, Marne la Vallee, France) was used for the analysis of apoptotic changes.

Real-time reverse transcription polymerase chain reaction $(R T-P C R)$. The expression of mRNA in Saos-2 osteosarcoma cells was determines by using real-time RT-PCR. For this purpose, a total of $2 \times 10^{6}$ cells were cultured in $100-\mathrm{mm}$ dishes containing DMEM medium and tumstatin and incubated for $48 \mathrm{~h}$. The cells were then collected to extract the RNA using an RNeasy Plus Mini kit (Qiagen, Waco, TX, USA). RT-PCR analysis was carried out using SuperScript III First-Strand Synthesis SuperMix for qRT-PCR (Invitrogen, Carlsbad, CA, USA). NanoDrop 1000 (Thermo Fisher Scientific, Wilmington, DE, USA) was used for the determination of concentration of each cDNA after adjustment to $40 \mathrm{ng} / \mathrm{ml}$ using diethylpyrocarbonate (DPEC) water. FAM-labeled TaqMan probes and TaqMan Universal Master Mix (Applied Biosystems) using Chromo4 (Bio-Rad Laboratories, Cambridge, MA, USA) were employed to carry out the real-time PCR with the primers listed in Table I. The PCR sequence involved 2 -min incubation at $50^{\circ} \mathrm{C}, 10$-min denaturation at $50^{\circ} \mathrm{C}$ followed by $15 \mathrm{sec} 50$ cycles at $95^{\circ} \mathrm{C}$ and then $1 \mathrm{~min}$ at $60^{\circ} \mathrm{C}$. GAPDH was used as an internal control. Analysis of the PCR products was performed on $2 \%$ agarose gel using ethidium bromide and a UV illuminator was used for the visualized.

Western blot analysis. Tumstatin, TNF- $\alpha$-treated or untreated control Saos-2 cells were suspended in DMEM medium containing $1.5 \mu \mathrm{M}$ aprotinin, $5 \mu \mathrm{M}$ AEBSF, $0.01 \mu \mathrm{M}$ leupeptin, $10 \mu \mathrm{M} \mathrm{E}-64$ and phosphatase inhibitors [1 mM sodium orthovanadate $\left(\mathrm{Na}_{2} \mathrm{VO}_{4}\right) ; 1 \mathrm{mM}$ sodium molybdate $\left(\mathrm{Na}_{2} \mathrm{MoO}_{4}\right) 4 \mathrm{mM}$ sodium tartrate dihydrate; $2 \mathrm{mM}$ imidazole were obtained from Sigma-Aldrich]. The cell plates were kept for a period of $30 \mathrm{~min}$ on ice prior to centrifugation at $12,000 \mathrm{x} \mathrm{g}$ for $30 \mathrm{~min}$ to collect the supernatant. The bicinchoninic protein assay kit (Pierce, Rockford, IL, USA) was used for the analysis of the concentration of proteins. The $30 \mu \mathrm{g}$ protein samples were isolated using $10 \%$ SDS-PAGE gel followed by transfer to polyvinylidene difluoride membrane (Bio-Rad Laboratories, Hercules, CA, USA) using electroblotting. Following incubation for $1 \mathrm{~h}$ in a blocking solution for phosphorylated proteins (Blocking One-P; Nacalai Tesque, Kyoto, Japan), the membranes were washed with PBS-Tween followed by overnight incubation with primary antibodies. Then the membranes were rinsed twice for $10 \mathrm{~min}$ each time in PBS and $0.05 \%$ Tween-20 before incubation with horseradish peroxidase-conjugated polyclonal horse anti-rabbit $(1: 2,000$; Cell Signaling Technology, Inc., Danvers, MA, USA) for $1 \mathrm{~h}$. The blot was developed using an enhanced chemiluminescence kit (Intron Biotechnology, Inc., Seongnam, Korea).

DNA construction and transfection. HEK293 cells seeded in plastic dishes were cultured in DMEM medium supplemented with FBS until attaining $80 \%$ confluence. The cells were washed with PBS and then treated with a mixture of DNA 


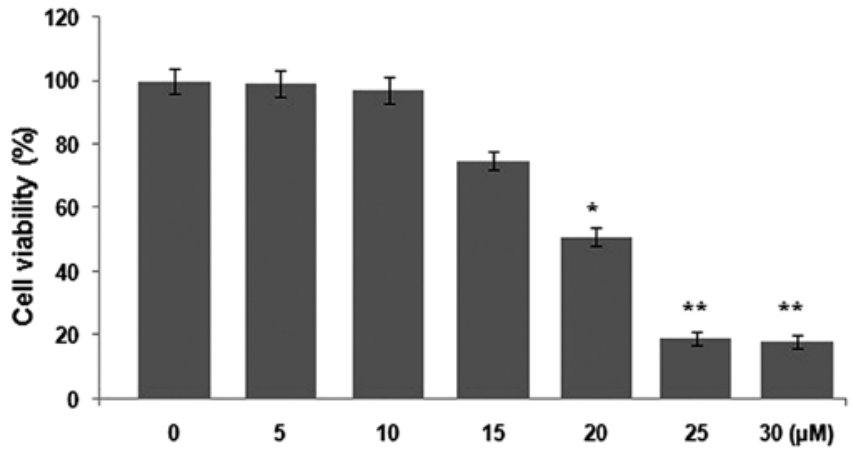

Figure 1. Effect of tumstatin on viability of Saos-2 cells. Saos-2 cells grown in 96-well plates were treated for $48 \mathrm{~h}$ with various concentrations of tumstatin and the cell viability was determined by the MTT assay. The activity was compared to the control well of the same cell line and results are expressed as a percentage of the control (mean \pm SEM). Significant differences from the control cultures are indicated by an asterisk; ${ }^{*} \mathrm{P}<0.05$, ${ }^{* * *} \mathrm{P}<0.01$ (Student's t-test).

and Opti-MEM. QuickChange II Site-Directed Mutagenesis kit (Stratagene, La Jolla, CA, USA) was used for the transfection of p65NF- $\kappa \mathrm{B}$ S536A carrying alanine instead of serine at 536 position. The cells were then incubated with tumstatin for $180 \mathrm{~min}$ at $37^{\circ} \mathrm{C}$ in D-MEM containing $10 \% \mathrm{FBS}$.

Statistical analysis. For the analysis of the data the unpaired Student's t-test (Graph Pad Prism V.4) was used and P-values of $<0.05$ were considered statistically significant.

\section{Results}

Inhibition of Saos-2 cell viability by tumstatin. Saos-2 cells were treated with various concentrations $(5,10,15,20,25$ and $30 \mu \mathrm{M}$ ) of tumstatin for $48 \mathrm{~h}$ and then analyzed by MTT assay. Tumstatin treatment reduced the viability of Saos- 2 cells in a concentration-dependent manner after $48 \mathrm{~h}$. No significant effect was observed on the viability of Saos- 2 cells treated with 5 and $10 \mu \mathrm{M}$ concentrations of tumstatin for $48 \mathrm{~h}$. However, cell viability was reduced significantly by the concentration of $15 \mu \mathrm{M}$ with maximum inhibition at $25 \mu \mathrm{M}$ (Fig. 1). At $25 \mu \mathrm{M}$ concentration of tumstatin after $48 \mathrm{~h}$, viability of Saos- 2 cells was reduced to $19 \%$ compared to $100 \%$ in the control cultures (Fig. 1).

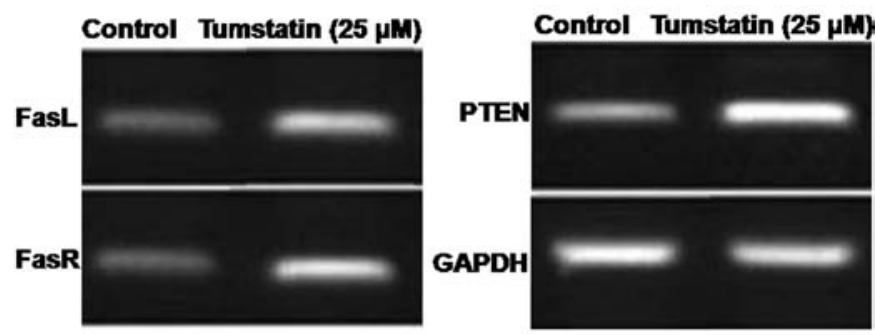

Figure 3. Expression of PTEN, FasL and FasR mRNA in Saos-2 cells treated with tumstatin. After having reached confluence, Saos-2 cells were treated with $25 \mu \mathrm{M}$ of Saos- 2 for various time-points and semi-quantitative analysis of PTEN, FasL and FasR mRNA was done with the mRNA amplified by 32 cycles in Saos-2 cells. The RT-PCR product of GAPDH prepared from the same samples and amplified for 29 cycles is also shown.

Tumstatin induces apoptosis in Saos-2 cells. Analysis of the apoptosis induction in Saos-2 cells using Hoechst 33342 staining revealed presence of characteristic apoptotic nuclei on treatment with $25 \mu \mathrm{M}$ concentration of tumstatin after $48 \mathrm{~h}$. The cells were seen to be rounded in shape and shrunken in size. However, no apoptotic nuclei were observed in the control Saos-2 cell cultures after $48 \mathrm{~h}$ (Fig. 2). Increase in the concentration of tumstatin from 15 to $25 \mu \mathrm{M}$ enhanced the proportion of apoptotic cells significantly compared to the control cells. The DNA fragmentation pattern showed formation of ladder like structures on tumstatin treatment for 48 h (Fig. 2).

Effect of tumstatin on the expression level of PTEN, FasL and FasR mRNA in Saos-2 cells. The effect of tumstatin on the expression of PTEN, FasL and FasR mRNA following amplification of cDNA for 40 cycles revealed a significant increase after 30 min (Fig. 3). However, tumstatin exhibited no effect on the expression of mRNA corresponding to GAPDH which was constitutively expressed in Saos-2 cells (Fig. 3).

Effect of tumstatin on $I \kappa-B \alpha$ regulation in Saos -2 cells. The effect of tumstatin and TNF- $\alpha$ on the expression of $\mathrm{I} \kappa \mathrm{B} \alpha$ in Saos- 2 cells was analyzed using western blot assay. The results revealed that expression of $\mathrm{I} \kappa \mathrm{B} \alpha$ was reduced up to $90 \mathrm{~min}$ by tumstatin treatment and was then increased by $180 \mathrm{~min}$. However, treatment of Saos-2 cells with $10 \mathrm{ng} / \mathrm{ml}$ TNF- $\alpha$ as the control inhibited the expression of I $\kappa \mathrm{B} \alpha$ after $30 \mathrm{~min}$ (Fig. 4). The expression level of $\mathrm{I} \kappa \mathrm{B} \alpha$ increased by
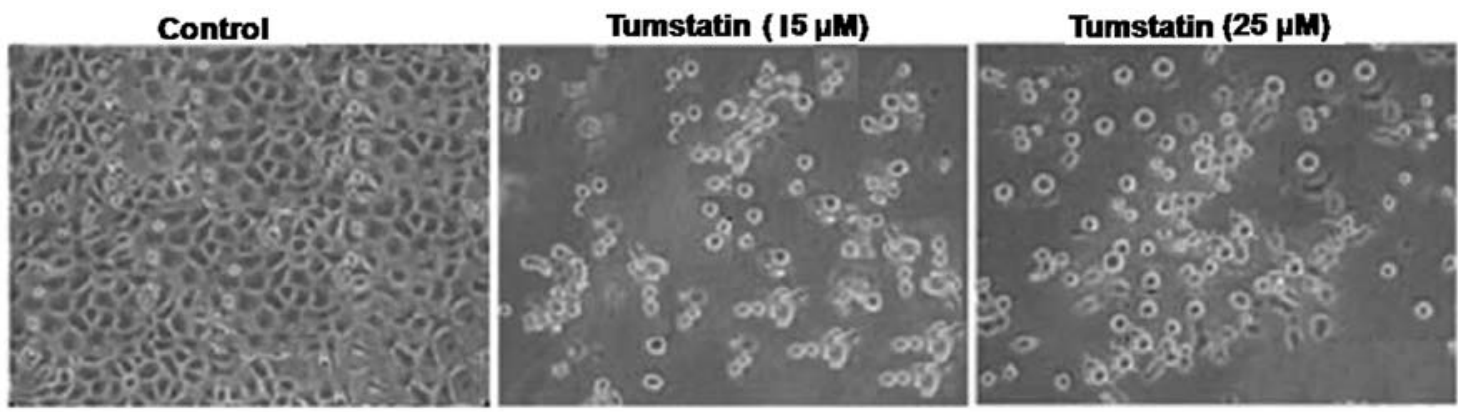

Figure 2. Nuclear fragmentation of Saos-2 cells treated with tumstatin. (A) Nuclear morphology of Saos-2 cells treated with tumstatin. Saos-2 cells were treated for $48 \mathrm{~h}$ with tumstatin. Cells were stained with Hoechst 33342 and observed under a fluorescent microscope. Bar represents $10 \mu \mathrm{m}$. (B) DNA ladder formation in tumstatin-treated Saos-2 cells. Saos-2 cells were exposed for $48 \mathrm{~h}$ to various concentrations of tumstatin indicated. DNA was extracted and analyzed on an agarose gel. Lane M, standard DNA markers; arrow indicates $500 \mathrm{bp}$. 


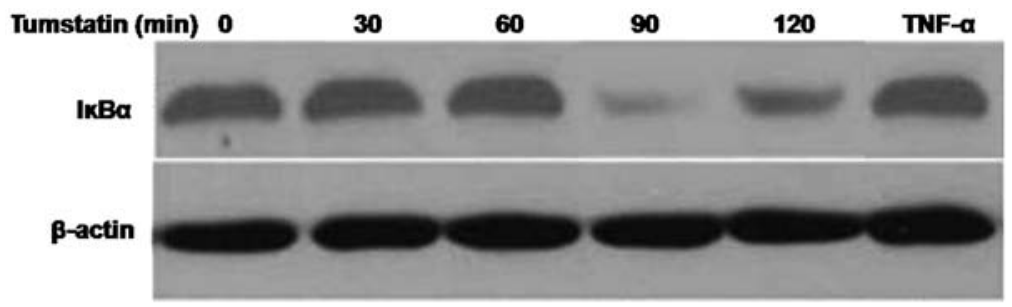

Figure 4. Regulation of IкB $\alpha$ protein in Saos-2 cells treated with tumstatin. Saos- 2 cells were treated with $25 \mu \mathrm{M}$ CA or $10 \mathrm{ng} / \mathrm{ml}$ TNF- $\alpha$ for the variable time periods indicated and cell lysates were prepared from each type of culture. Samples (10 $\mu \mathrm{g})$ were separated on a 10\% of SDS-PAGE gel, transferred to a PVDF membrane, and analyzed for IкB $\alpha$ expression by western blotting.

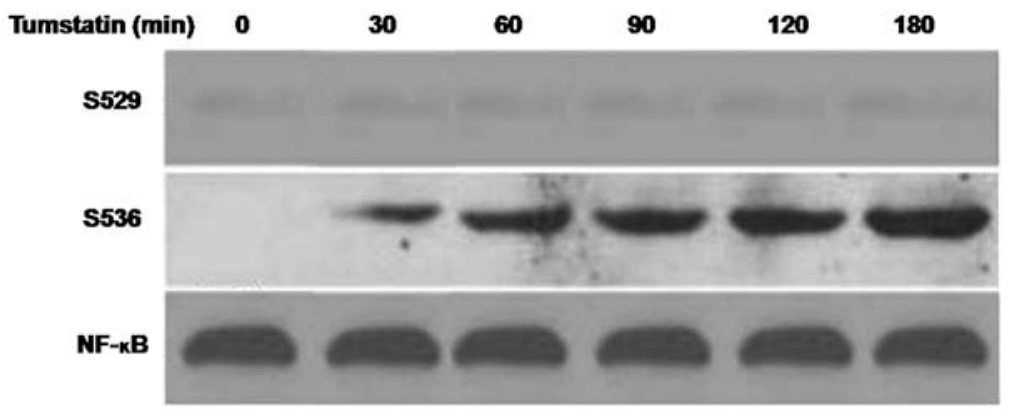

Figure 5. Western blot analysis of phospho-NF-кB in Saos-2 cells. (A) Cell lysates were prepared from Saos-2 cells treated with $25 \mu \mathrm{M}$ concentration of

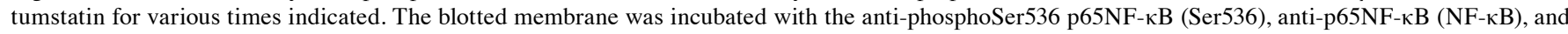
anti-phosphoSer529 p65NF-kB (S529) antibodies. (B) The cells were treated for $3 \mathrm{~h}$ with various concentrations of tumstatin as indicated. The samples were analyzed by western blotting using anti-phospho-Ser536 p65NF- $\mathrm{kB}$ antibody (S536). The antibody was stripped off the membrane and replaced with anti-

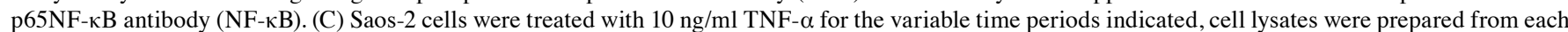

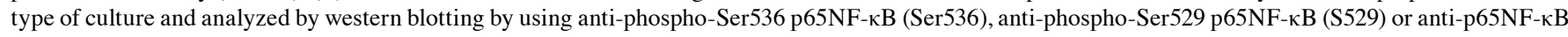
(NF-kB) antibodies.

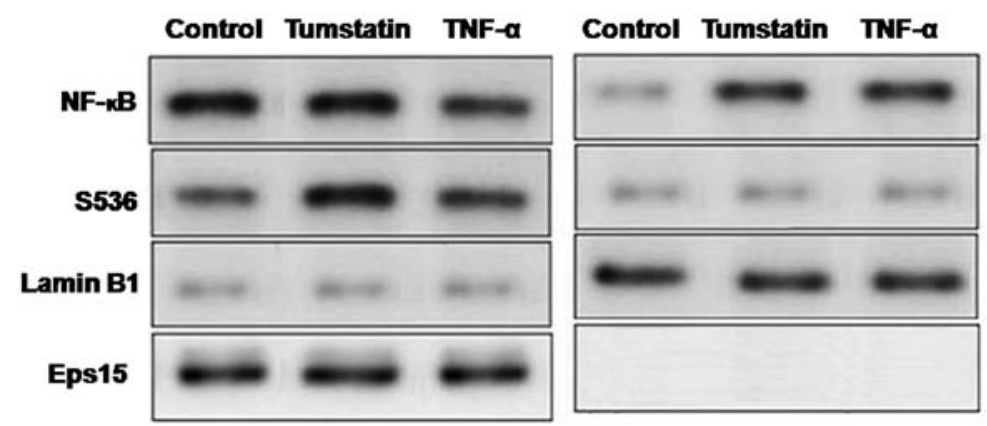

Figure 6. Nuclear translocation of NF- $\mathrm{\kappa B}$ in Saos-2 cells treated with tumstatin. Saos-2 cells were treated with tumstatin or $10 \mathrm{ng} / \mathrm{ml} \mathrm{TNF}-\alpha$ for various time-points. Cell fractionation was done to prepare the cytosolic (left panel) and nuclear (right panel) fractions. Proteins prepared from each fraction were

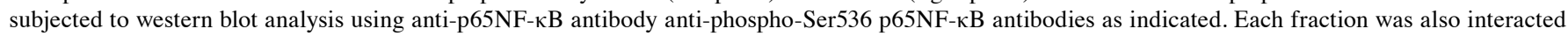
with antiEps15 and anti-Lamin B1 antibodies to ensure the purity of cytosolic and nuclear fractions, respectively.

60 min and became similar to those of untreated control cells.

Effect of tumstatin on phosphorylation of $N F-\kappa B$. The interaction of anti-phospho-Ser536 p65NF- $\mathrm{BB}$ antibody. Incubation with anti-p65NF- $\kappa \mathrm{B}$ antibody also led to a strong interaction with $65-\mathrm{kDa}$ band. The interaction of antiphospho-Ser529 p65NF- $\kappa$ B and anti-p65NF- $\kappa$ B antibodies with $65-\mathrm{kDa}$ band remained independent on treatment with tumstatin (Fig. 5). The interaction of anti-phospho-Ser536 p $65 \mathrm{NF}-\kappa \mathrm{B}$ antibody with proteins of tumstatin treated cells showed a concentration dependent increase (Fig. 5). However, the interaction was found to be very weak in case of untreated control cells. Following removal of antiphospho-Ser536 p65NF- $\mathrm{BB}$ antibody and then incubation with anti-p65NF- $\kappa B$ antibody, interaction was observed. Treatment of the cells with $10 \mathrm{ng} / \mathrm{ml}$ concentration of TNF- $\alpha$ resulted interaction of antiphospho-Ser529 p65NF- $\mathrm{kB}$ and anti-phospho-Ser536 antibodies with $65-\mathrm{kDa}$ protein. The interaction increased after $5 \mathrm{~min}$ and was maximum after 15 and $60 \mathrm{~min}$, respectively for antiphospho-Ser529 p65NF- $\mathrm{B}$ and anti-phospho-Ser536 antibodies (Fig. 5).

Effect of tumstatin on translocation of $N F-\kappa B$ in Saos-2 cells. Saos- 2 cells were treated with $25 \mu \mathrm{M}$ concentration of tumstatin and $10 \mathrm{ng} / \mathrm{ml}$ concentration of TNF- $\alpha$. 


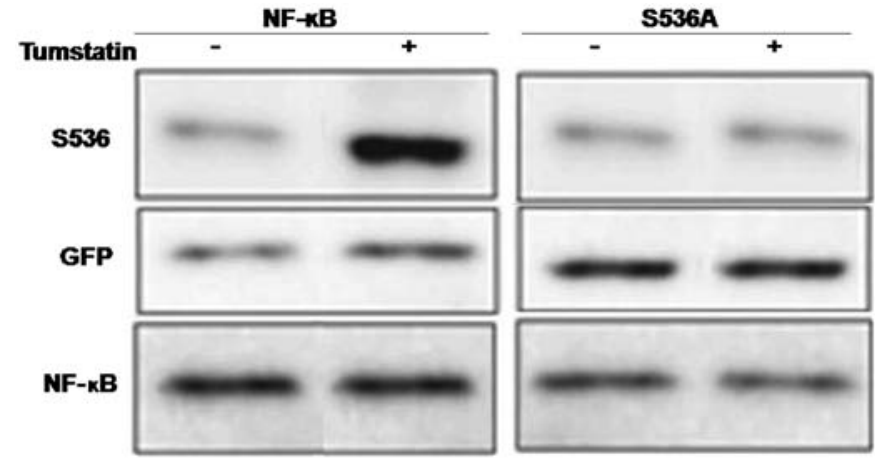

Figure 7. Phosphorylation of NF- $\kappa B$ in the cells transfected with the mutant p65NF- $\kappa$ B. HEK 293 cells were transfected with GFP-NF- $\kappa B$ and GFPS536A plasmid and treated with or without tumstatin. Cell lysates were prepared from each type of culture and analyzed by western blotting using

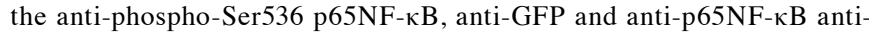
bodies.

Interaction of anti-p65NF- $\mathrm{kB}$ antibody and $65-\mathrm{kDa}$ protein band was observed in the cytosolic fractions of both untreated and tumstatin-treated cells (Fig. 6). However, this interaction was observed at higher level in the nuclear fraction of only tumstatin-treated but not in untreated control cells. In untreated control cells none of the proteins interacted with anti-phospho-Ser536 p65NF- $\mathrm{BB}$ antibody (Fig. 6). In tumstatin treated cells interaction of anti-phospho-Ser536 p65NF- $\mathrm{BB}$ antibody with proteins was significant both in the cytosolic and nuclear fractions. The interaction of anti-phospho-Ser536 p65NF- $\mathrm{BB}$ antibody with the proteins of cytosolic and nuclear fractions was also observed in the TNF- $\alpha$ treated cells. In both tumstatin and TNF- $\alpha$-treated cells interaction of anti-Eps15 antibody was found in cytosolic but not in nuclear fraction (Fig. 6). Analysis of the interaction of anti-Lamin B1 antibody with $68-\mathrm{kDa}$ protein band was found in the nuclear, but not in cytosolic fraction.

In vitro dephosphorylation and phosphorylation ofmutant gene products. Activation of the Ser536 of p65NF- $\mathrm{kB}$ by tumstatin treatment was confirmed by transfection of HEK293 cells with mutant p65NF- $\mathrm{BB}$ gene possessing alanine (GFP-S536A) instead of serine at 536. In both control and tumstatin treated cells transfected with GFP-S536A mutant gene, no interaction of anti-phospho-Ser536 p65NF-кB antibody was observed with any of the proteins (Fig. 7). On the contrary, interaction of anti-phospho-Ser536 p65NF-kB antibody with proteins of tumstatin treated cells increased significantly.

\section{Discussion}

The present study demonstrates the viability of inhibitory and apoptosis inducing effect of tumstatin on Saos-2 osteoblastic carcinoma cells. MTT assay was used for analysis of reduction in viability and phase-contrast microscopy for analysis of alterations in morphology of Saos- 2 cells following tumstatin treatment. The results from viability assay revealed significant reduction in concentration-dependent manner on treatment with tumstatin for $48 \mathrm{~h}$. The cells became round and shrunken, DNA showed fragmentation and ladder-like pattern following tumstatin treatment at $25 \mu \mathrm{M}$. Therefore, tumstatin treatment significantly induced apoptosis in Saos-2 cells in a dosedependent manner. Studies have demonstrated that PTEN, FasR and FasL play a vital role in the induction of apoptosis through NF- $\mathrm{KB}$ pathway (24). Various cell apoptosis is induced via the NF- $\kappa B$ pathway by increase in the expression of PTEN, FasR and FasL $(25,26)$. Investigation of the mRNA expression corresponding to PTEN, FasL and FasR in Saos-2 cells revealed significant increase in tumstatin-treated cells. These findings indicated that tumstatin exhibited apoptosis inducing effect through increase in the expression level of PTEN, FasL and FasR.

Results from the present study revealed that tumstatin treatment activated $\mathrm{p} 65 \mathrm{NF}-\mathrm{\kappa B}$ by phosphorylation of serine on position 536. TNF- $\alpha$ also led to the activation of p65NF- $\kappa B$ by phosphorylation of serine at position 536 in Saos-2 cells. Phosphorylation of p65NF- $\mathrm{kB}$ at position 536 serine is well known and this study also demonstrated the same (27-29). Therefore, tumstatin induced phosphorylation of p65NF- $\mathrm{kB}$ at position 536 serine observed in the present study is also confirmed. In most of the studies on p65NF- $\mathrm{BB}$, it has been observed that serine is phosphorylated on position 536 $(27,30,31)$. Overexpression studies with the activated Akt revealed that IKK is necessary for enhanced p65NF- $\mathrm{B}$ transactivation, whereas mutation of Ser536 abolishes this effect (31). Our results revealed that tumstatin treatment also induced activation of p65NF- $\mathrm{KB}$ in Saos- 2 cells by phosphorylation of serine present on position 536. Thus, NF- $\kappa B$ is activated by phosphorylation of serine on position 536 in the Saos- 2 cells treated with tumstatin. The present study also demonstrated that activation of p65NF- $\mathrm{kB}$ induced its translocation into the nucleus in Saos-2 cells. Phosphorylation of Ser536 on p65NF-кB can be detected both in the cytoplasm and the nucleus.

Activation of NF- $\kappa \mathrm{B}$ stimulates the expression of $\mathrm{I} \kappa \mathrm{B} \alpha$ which exhibits inhibitory effect on the phosphorylation of NF- $\mathrm{KB}$ (32). The present study revealed that treatment of Saos- 2 cells with TNF- $\alpha$ inhibited IкB $\alpha$ expression and therefore enhanced the nuclear translocation of NF- $\kappa \mathrm{B}$. Tumstatin treatment also inhibited the expression of IкB $\alpha$ in Saos-2 cells, but the effect was weak compared to TNF- $\alpha$. Therefore, tumstatin treatment leads to the activation of $N F-\kappa B$ in a manner independent of IкB $\alpha$.

In conclusion, the present study demonstrates that tumstatin inhibits viability and induces apoptosis in Saos-2 osteosarcoma cells through NF- $\mathrm{kB}$ activation pathway. Therefore, tumstatin shows promise for the treatment of osteosarcoma.

\section{References}

1. Tarkkanen M, Karhu R, Kallioniemi A, Elomaa I, Kivioja AH, Nevalainen J, Böhling T, Karaharju E, Hyytinen E, Knuutila S, et al: Gains and losses of DNA sequences in osteosarcomas by comparative genomic hybridization. Cancer Res 55: 1334-1338, 1995.

2. Al-Romaih K, Bayani J, Vorobyova J, Karaskova J, Park PC, Zielenska $\mathrm{M}$ and Squire JA: Chromosomal instability in osteosarcoma and its association with centrosome abnormalities. Cancer Genet Cytogenet 144: 91-99, 2003.

3. Ragland BD, Bell WC, Lopez RR and Siegal GP: Cytogenetics and molecular biology of osteosarcoma. Lab Invest 82: 365-373, 2002.

4. He JP, Hao Y, Wang XL, Yang XJ, Shao JF, Guo FJ and Feng JX: Review of the molecular pathogenesis of osteosarcoma. Asian Pac J Cancer Prev 15: 5967-5976, 2014. 
5. Broadhead ML, Clark JC, Myers DE, Dass CR and Choong PF: The molecular pathogenesis of osteosarcoma: A review. Sarcoma 2011: 959248, 2011.

6. Kansara M and Thomas DM: Molecular pathogenesis of osteosarcoma. DNA Cell Biol 26: 1-18, 2007.

7. Tabone MD, Kalifa C, Rodary C, Raquin M, Valteau-Couanet D and Lemerle J: Osteosarcoma recurrences in pediatric patients previously treated with intensive chemotherapy. J Clin Oncol 12: 2614-2620, 1994

8. Kempf-Bielack B, Bielack SS, Jurgens H, Branscheid D, Berdel WE, Exner GU, Göbel U, Helmke K, Jundt G, Kabisch SF, et al: Osteosarcoma relapse after combined modality therapy: An analysis of unselected patients in the Cooperative Osteosarcoma Study Group (COSS). J Clin Oncol 23: 559-568, 2005.

9. Davis AM, Bell RS and Goodwin PJ: Prognostic factors in osteosarcoma: A critical review. J Clin Oncol 12: 423-431, 1994.

10. Arends MJ and Wyllie AH: Apoptosis: mechanisms and roles in pathology. Int Rev Exp Pathol 32: 223-254, 1991.

11. Jacobson MD, Weil M and Raff MC: Programmed cell death in animal development. Cell 88: 347-354, 1997.

12. Cross TG, Scheel-Toellner D, Henriquez NV, Deacon E, Salmon M and Lord JM: Serine/threonine protein kinases and apoptosis. Exp Cell Res 256: 34-41, 2000.

13. Aggarwal BB and Takada Y: Pro-apoptotic and anti-apoptotic effects of tumor necrosis factor in tumor cells. Role of nuclear transcription factor NF- $\kappa$ B. Cancer Treat Res 126: 103-127, 2005.

14. Graham B and Gibson SB: The two faces of NF- $\kappa \mathrm{B}$ in cell survival responses. Cell Cycle 4: 1342-1345, 2005.

15. Lamkanfi M, Declercq W, Van den Berghe T and Van den Abeele P: Caspases leave the beaten track: caspase-mediated activation of NF-kB. J Cell Biol 173: 165-171, 2006.

16. Piva R, Belardo G and Santoro MG: NF-кB: a stress-regulated switch for cell survival. Antioxid Redox Signal 8: 478-486, 2006.

17. Radhakrishnan SK and Kamalakaran S: Pro-apoptotic role of NF- $\mathrm{BB}$ : implications for cancer therapy. Biochim Biophys Acta 1766: 53-62, 2006

18. Maeshima Y, Colorado PC, Torre A, Holthaus KA, Grunkemeyer JA, Ericksen MB, Hopfer H, Xiao Y, Stillman IE and Kalluri R: Distinct antitumor properties of a type IV collagen domain derived from basement membrane. J Biol Chem 275 21340-21348, 2000

19. Hamano Y and Kalluri R: Tumstatin, the NC1 domain of $\alpha 3$ chain of type IV collagen, is an endogenous inhibitor of pathological angiogenesis and suppresses tumor growth. Biochem Biophys Res Commun 333: 292-298, 2005.

20. Pasco S, Brassart B, Ramont L, Maquart FX and Monboisse JC: Control of melanoma cell invasion by type IV collagen. Cancer Detect Prev 29: 260-266, 2005.
21. Pasco S, Ramont L, Venteo L, Pluot M, Maquart FX and Monboisse JC: In vivo overexpression of tumstatin domains by tumor cells inhibits their invasive properties in a mouse melanoma model. Exp Cell Res 301: 251-265, 2004.

22. Kawaguchi T, Yamashita Y, Kanamori M, Endersby R, Bankiewicz KS, Baker SJ, Bergers G and Pieper RO: The PTEN/ Akt pathway dictates the direct alphaVbeta3-dependent growthinhibitory action of an active fragment of tumstatin in glioma cells in vitro and in vivo. Cancer Res 66: 11331-11340, 2006.

23. Chung IS, Son YI, Ko YJ, Baek CH, Cho JK and Jeong HS: Peritumor injections of purified tumstatin delay tumor growth and lymphatic metastasis in an orthotopic oral squamous cell carcinoma model. Oral Oncol 44: 1118-1126, 2008.

24. Tanaka Y, Singh S and Aggarwal BB: Identification of a p65 peptide that selectively inhibits NF- $\mathrm{BB}$ activation induced by various inflammatory stimuli and its role in down-regulation of NF- $\kappa \mathrm{B}-$ mediated gene expression and up-regulation of apoptosis. J Biol Chem 279: 15096-15104, 2004.

25. Fujita M, Goto K, Yoshida K, Okamura H, Morimoto H, Kito S, Fukuda $J$ and Haneji T: Okadaic acid stimulates expression of Fas receptor and Fas ligand by activation of nuclear factor kappa-B in human oral squamous carcinoma cells. Oral Oncol 40: 199-206, 2004.

26. Bertram J, Peacock JW, Tan C, Mui AL, Chung SW, Gleave ME, Dedhar S, Cox ME and Ong CJ: Inhibition of the phosphatidylinositol 3'-kinase pathway promotes autocrine Fas-induced death of phosphatase and tensin homologue-deficient prostate cancer cells. Cancer Res 66: 4781-4788, 2006.

27. Yang F, Tang E, Guan K and Wang CY: IKK $\beta$ plays an essential role in the phosphorylation of RelA/p65 on serine 536 induced by lipopolysaccharide. J Immunol 170: 5630-5635, 2003.

28. Doyle SL, Jefferies CA and O'Neill LA: Bruton's tyrosine kinase is involved in p65-mediated transactivation and phosphorylation of p65 on serine 536 during NFkB activation by lipopolysaccharide. J Biol Chem 280: 23496-23501, 2005.

29. Shiraki K, Yamanaka T, Inoue H, Kawakita T, Enokimura N, Okano H, Sugimoto K, Murata K and Nakano T: Expression of TNF-related apoptosis-inducing ligand in human hepatocellular carcinoma. Int J Oncol 26: 1273-1281, 2005.

30. Sakurai H, Chiba H, Miyoshi H, Sugita T and Toriumi W: IкB kinases phosphorylate $\mathrm{NF}-\kappa \mathrm{B}$ p65 subunit on serine 536 in the transactivation domain. J Biol Chem 274: 30353-30356, 1999.

31. Madrid LV, Mayo MW, Reuther JY and Baldwin AS Jr: Akt stimulates the transactivation potential of the RelA/p65 subunit of NF- $\kappa$ B through utilization of the I $\kappa$ B kinase and activation of the mitogen-activated protein kinase p38. J Biol Chem 276: 18934-18940, 2001.

32. Sasaki CY, Barberi TJ, Ghosh P and Longo DL: Phosphorylation of RelA/p65 on serine 536 defines an I $\kappa \mathrm{B} \alpha$-independent NF- $\kappa \mathrm{B}$ pathway. J Biol Chem 280: 34538-34547, 2005. 